\title{
Seasonal Mythologies in the Lyrics of Cowboy Junkies
}

\author{
Rick Wallach \\ University of Miami (retired), Coral Gables, Florida, USA
}

\begin{abstract}
In many of his most memorable ballads, Cowboy Junkies lyricist and lead guitarist Michael Timmins combines imagery of seasonal change, of the year, notably of Winter, with religious and mythological references to create richly textured metaphors and analogies of love, loss and anguish. Some of the band's songs which display these symbolic networks and thematic linkages which we Will consider here are "Winter's Song," "'Cause Cheap is How I Feel," “Crescent Moon,” "First Recollection,” “Sad to See the Season Go,” “Good Friday” and "Ring on the Sill.” We will show that Timmins succeeds not only in rendering vivid tableaux of life in a world where Winter dominates the seasonal round, but also in making those exterior visions, in effect, objective correlatives of the inner lives of the characters of his ballads.
\end{abstract}

Keywords: Canadian rock, progressive rock, ballads, lyrics, poetry, mythlogy, folklore, metaphor

\section{Introduction}

In "Equine Gothic” Jerry Leith Mills famously wrote that truly southern literature had to have a dead mule in it (Mills, 1996, pp. 2-17). As a counterpoint, some years ago, a journalist asked Cowboy Junkies vocalist Margo Timmins what characterized an authentic Canadian national music and she replied, "It would have to have winter in it." ${ }^{1}$ Of course. Winter is the essential departure point for any conversation about Michael Timmins’ lyrics, or for that matter, about the artistry of the band he co-founded, Cowboy Junkies. The defining season of Canadian experience is his touch stone allegory. As a subject of the band's songs, or imagery occupying their background, that long, hostile season is always immanent.

Llamas_-serious fans of the band, in their own parlance-are spread upon the Earth and many are habitués of climates where obstinate winters happen so rarely they would be memorable for their rarity. Our neighbors to the north do seem to understand this about Americans, regarding our temperate latitude naïveté with equal parts amusement and envy. In early 2003 while introducing their as yet unrecorded ${ }^{2}$ song "Cold Evening Wind," Margo Timmins chided a group of American llamas who were following the band across Ontario as far as North Bay during their “'Blowin' and 'Driftin'” tour: "Some of them come from some southern states and don't know about llama underwear or... the Canadian winter. They're about to find out.”’ Since here in the lower forty-eight our snowdrops and crocuses have already yielded up their ghosts by early March, you can understand why, for

Rick Wallach (retired), Lecturer, MA Theology, MA Literature and Psychology. Roosevelt University, the University of Miami, and Nova Southeastern University.

1 Margo Timmins, personal communication.

2 The song was finally recorded on Notes Falling Slow (2015), disc 4, track 4.

3 Cookie Crumbs (authorized bootleg, 2011) Volume 2: Blowin’ and Driftin, track 12. 
most of us down thisaway, protracted winters are difficult to imagine. For most Canadians, though, that's just how the world is. Peter Moore, the Junkies' legendary recording engineer, declaims "winter is always there, man. We know that for most of the year we can freeze to death up here. It's no game. We better have lots of wood cut up or we're in trouble.”4 In the Junkies' ballads, that woodpile becomes an ironic image. Winter is already with you in July as you're your chopping wood. Growing on the front porch or in the yard throughout the spring, summer and early fall, the woodpile reassures with its promise of life-giving warmth when winter closes in and the darkness drops again. Then it reminds the cold and snowbound of the brief warm seasons of its harvesting even as its consumption evokes the truculence of its season of sacrifice. In Junkies songs this reminder is often tinctured with bitterness. "I've sat and watched the woodpiles grow through the summer," notes the despairing father of "First Recollection," but "Now I'm sitting, smelling summer burn through the fall." 5 Will there be anything left to burn by winter's depths? This is, really, a question both metaphorical and literal which pervades so many of the band's songs, if not in those exact words, then surely in their spirit.

\section{Winter: The Master Trope}

Michael Timmins is an extraordinarily "novelistic” songwriter, if I may extenuate a metaphor here. Winter as lyric becomes much more than applied meteorology. It is a resonating chamber, the master trope around —and within-which he builds his stories or sets their tone, or through which we listen for hints and disclosures about the inner as well as the outer lives of his characters. Even while the season, spent, husbands its vitriol through the warmer months for the reaches of autumn, these characters bear it within themselves in the spiritual wounds they carry, in their guilt and frustration, failures and their loneliness. Beyond a function of climate, his songs render the seasons as interior as well as exterior landscapes. They become all but the natural habitats of the soul, expressive of its unmet yearnings, anguish and fears, but most importantly, perhaps, allegories of our terror of isolation in every sense, but especially the spiritual.

Moreover "natural" in the context of a Junkies song is rarely a comforting word, as in Hamlet's "heart-ache, and the thousand natural shocks / That flesh is heir to.” These wintry settings are objective correlatives of desire in its many thwarted forms, from anger that paralyzes love to anxieties which shrink from affection. Images from the band's most memorable songs linger in your imagination like virtual experiences of the cold. Timmins' lyrics resonate with winter's advent even whensnowmelt announces its recession in the spring. Inevitability, in the north, comes mantled in white and translucent blue like one of Lawren Harris's arctic landscapes wherein all other manifestations of natural law are secondary to it. Spring, summer and fall, fleeting, seem to exist only because of the inattention of their fiercer sibling. Those long frigid months, more than any other environmental influence, shape the band's lyrical mindset.

Even as winter encompasses them, the protagonists of Cowboy Junkies songs often dare not speak its name. There's no need to name it because it's so familiar. Timmins, meanwhile, treats it like some demiurge best not excessively invoked. His characters acknowledge other features of wintry ambience like the cold or snow or isolation, but rarely the name of season itself. In both "Winter's Song" ${ }^{6}$ and "Ring on

\footnotetext{
4 Peter Moore, personal communication.

${ }^{5}$ Pale Sun, Crescent Moon: RCA (1993), track 2.

${ }^{6}$ Black Eyed Man: RCA (1992), track 7.
} 
the Sill,"7 for example, it is "the siege to come.” In "Cause Cheap is How I Feel” it's the kind of night that freezes your spit, and your soul, in midair. When the "cold and tired" narrator of "Crescent Moon" addresses the lunar spirit who beckons him with the quietude of her "iron bed” he asks "Do I dare to speak your name?” Like that spirit's deathly hand, winter's "skeletal arms embrace the withering day" in "Sad to see the Season Go." Exceptionally, it is pronounced as a synonym for suicidal despair, as in "First Recollection": "Winter's coming on, days getting dreary / And I think that this is the season when I leave you all.” We could say in Timmins' poetry "it's an entropic field created by all dying things. It surrounds us and penetrates us; it binds our culture together."

Nevertheless Timmins' winter can't be formulated like a theodicy wherein cold is mere absence of warmth the way evil was mere absence of the Holy Spirit to medieval theologians. Its cold is aggressive, with an agency all its own even if, in many cases, its activity seems entropic. Timmins depicts the childhood memory of a "black iron steam engine covered with ice" as some prehistoric monster "moaning and snorting" against the paralysis of its frozen jacket in "First Recollection.” The voice of the lunar goddess of "Crescent Moon”8 enunciates an awful irony, configuring her seductive blandishment in erotic terms while her touch is death itself: "I think once your body feels my hand / your mind will change and your heart will lose its pain.” Winter reminds us there is a perfection in death that life can never achieve.

\section{Eros, Agape, Amor: Tropes of Love and Warmth}

And yet, for all this bleakness, Timmins is artisanal about crafting darkness, the cold, the shrouds of snow to magnify by contrast the warmth of love, or perhaps more accurately, to hold in varying perspectives and explore our hope and desperate need for it. There is nothing simple about any form of love in the songs of Cowboy Junkies. It isn't necessarily the savior of the soul, it doesn't always endure—at times, like spring itself, it appears as ephemeral as a crocus_-and it can be the contrivance of a foible as often as an epiphany. We will explore its frangibility in other contexts below, but if winter is our poet's quintessentially Canadian master trope for existential isolation and emotional paralysis, then a fragile vision of love, which he often represents as delicately as he brutally depicts the cold, is all that opposes it.

Let's say the quintessential expression of love in the midst of winter in these songs is divine love proffered by the Lord. Its other manifestations are diminished gradients through which many of Timmins' characters seek a sublime source to reinvigorate their emotional lives, if not consciously than in mythic or spiritual terms. Amid the Hopkinsean sensibility of "Good Friday" the narrator stands at her window watching the world awaken from winter. The darkness, symbolized by the purple sky, yields to the golden glow of sunrise whose warmth transforms the cerement of fallen snow into "flowing water," a baptismal image with the power to fertilize her imagination and set her mind wandering. This peregrination of the mind, adumbrated by the red-tailed hawk "gracefully soaring" above her, contrasts with the snowbound mindset of winter, entrapment behind the transparent barrier of the window which, with the advent of spring warmth, should be a barrier no longer. The rising sun illuminates the "distant elms" with an orange flame reminiscent of Gerard Manley Hopkins'

\footnotetext{
7 Pale Sun, track 3.

8 Pale Sun, track 1.

9 Miles from our Home: Geffen (1998), track 4.
} 
Heraclitean Fire:

\author{
Million-fuelèd, | nature’s bonfire burns on. \\ But quench her bonniest, dearest | to her, her clearest-selvèd spark \\ Man, how fast his firedint, | his mark on mind, is gone! \\ Both are in an unfathomable, all is in an enormous dark \\ Drowned.... (Hopkins, 1985, p. 65)
}

The song invokes the liquid arc of the water cycle, with the falling rain which heralds the end of winter and promises seasonal rebirth. Cascading meltwater, "Water turned from ice / creek is roaring," assumes the role of a paschal hymn. The distant elms burning with sublime fire also suggest the crosses on Calvary ${ }^{10}$ tree" being a euphemism for Christ's cross, in both traditional usages and in modern poetic applications like Ezra Pound's "Ballad of the Goodly Fere:" "I ha' seen him eat o' the honey-comb / sin' they nailed him to the tree” (Pound, 1957, p. 9).

Timmins' simultaneous invocation of the liquid and solid aspects of water can also be found prominently in the final verse of another Junkies song rife with season mythos, "Sad to See the Season Go."11 A late autumnal dream of an awakening nature is "locked" within "imperfect dormant seeds" whose promise, in a vision suggesting the play of sunlight on rushing meltwater, engenders "A sparkling ambiguity / both liquid and solid at one time.” Here, as in “Crescent Moon,” nature is conceived as a feminine persona, first as the slain paraclete/bird of its opening stanza and finally as the apostrophe to the dream of resurgent nature: "Locked here these dreams of you." The seasonal cycle is itself married to the imagery of the Passion, where the "fresh wounds" of the falling bird yield "thick sheaves of love" and her lover, as it were, "lay open palm to her world.” As in "Good Friday," the cycles of nature are expressive of the birth and passion of the Savior who is both the salvator and sacrificial victim, another "sparkling ambiguity" effective at promulgating visions of life but, finally, unable to stand against the inevitability of death.

"Winter's Song” opens with the narrator's complaint “It’s cold where you brought me.” Is this a place, or a state of mind, of feeling? That her lover insists that love will "[find] the sun again" infers their relationship has experienced some unstated problem. They find themselves poised, like the couples in "Ring on the Sill" and "First Recollection," not within the depths of winter but on its cusp. The tension underlying this song, like the other two, is generated by its anticipation of worse weather, deepening cold—described here as "the siege," precisely as it is envisioned by the wife in "Ring." The lover anticipates that behind their upturned coat collars, like "ramparts" against this encroachingly hostile season, they will be cut off by the intimidating cold. He promises her that the warmth will return eventually and the crocuses will reemerge from their frozen tombs. Meanwhile the lone oak which scratches the sky—like the "skeletal arms" of the denuded trees in "Sad to See the Season Go"-reminds us that this is an urban landscape; these leaves aren't "declining in cyclic decay" as in "Sad to See the Season Go." They're "rotting at our feet” on cement sidewalks and asphalt streets. Nature is a prisoner not only of the season but also of the indifference of the cityscape the narrators inhabit. In this deadening

\footnotetext{
10 The image of the burning cross predates the familiar abuse of the symbol by the Ku Klux Klan; in perhaps the most relevant gesture for our purposes, it suggests the Pentecostal "tongues of fire” from Acts 2:3 as well as the protest of 10th-Century heresiarch Pierre de Bruys, who burned roods to protest the veneration of the material cross. See F. L. Cross; E. A. Livingstone , editors. The Oxford Dictionary of the Christian Church, 3rd edition. Oxford: Oxford University Press, 1997. p. 1264.

${ }^{11}$ Rarities, B-Sides and Slow, Sad Waltzes. Toronto: Latent Recordings (1999), track 3.
} 
environment the lovers can barely speak to one another. Their whispers, like the blown and heaped dead leaves at their feet, pile up at the foot of their bed.

\section{A Mythos of Sensuality: "Ring on the Sill”}

Establishing a symbolic hierarchy akin to the Gnostic upper and lower worlds, in "Ring on the Sill” minutiae of sensuality and domesticity reverberate with spiritual and mythological significance. The central archetype of this song is the circle- the wife's wedding ring, the ring of moisture beneath the husband's glass, but also the implicit cycle of the seasons - the waning summer, the onset of fall, the impending winter and implied re-awakening with spring. As the song opens a young woman contemplates the immanence of winter, the "siege," anticipating how she will miss the summer warmth, being outside "in the park / with the sun on her face" surrounded by the vitality of nature. She associates this warmth with tactile memories of her husband, of "the lingering taste that he left on her tongue.” Her consciousness is instinctively sensual: the smell of snow, the taste he left, the feel of the sun on her face. From her husband's perspective the impending cold also expresses the emotional and physical estrangement that has somehow interceded between them. It is an alienation firmly linked to the rhythms of the seasons by her association of what she'll miss about summer to her dwindling intimacy with her partner. In another constellation of opposed images the "cold fall air" contrasts with the "haunting" of his memory by his wife’s warm breath during their first kiss, which he recalls "immediately” upon awakening.

Beneath these poignant acts the background myth to this song is the hieros gamos or hierogamy, the sacred marriage or divine union of a sky and an earth deity. A symbolic celebration of the annual renewal of nature, in the sybillene fertility rituals described by J. G. Frazer in The Golden Bough a priestess anointed the head of the bridegroom at the outset of the symbolic marriage ceremony. In the song, as her husband puts the ring back on her finger, "she brushes back his hair." Before such ritual marriages were enacted symbolically, they were performed as sacrificial rites wherein a chosen victim was "married" to the goddess, then slain and dismembered after which his body was scattered in the fields to ensure their continued fertility. In "Ring on the Sill" the husband fears that intimacy permits another to "cut right through you," invoking the evisceration that accompanied such rituals of fecundity at their earliest horizon of enactment.

Other mythic gestures include the husband lifting his glass like a chalice leaving a ring of moisture whereupon he "sees a light from the window caress her like he knows he should," his moment of illumination or summons to renew the mystical marriage. These mixed images of water and light, as in "Good Friday," also bear Christian mythic allusions. They denote a typological process of awakening, illumination and coming to terms with the fear of spiritual death as well as invoking the baptismal font. When the husband "inhales the cold fall air," he symbolically accepts death as Christ did to initiate the process of rebirth. Also consistent with gnostic imagery here are the references to breath—“he'd taste her breath like a haunting," "he inhales the cold fall air." The sublimity of this symbolism is made explicit by the line "like a spell with each breath he'd taste her breath like a haunting, irritating as hell." That "breath" anticipates his subsequent inhalation of "the cold fall air," his assimilating to himself the impending death of nature which he will simultaneously resurrect through his renewal of his marital bond.

Closely linked to the breath, though in a contrasting manner, is the gentle sensuality of tasting: “...and that lingering taste that he left on her tongue" (with its own proximity to her gently sensual memory of "the sun on her 
face”) and his memory of how, upon awakening, he would "taste her breath." The erotic aspect of these remembered "tastes" aside, the metaphor of the tongue as symbol coordinates the deceptively mundane domestic images which impart to "Ring on the Sill" its concreteness: the sink full of unwashed dishes from which nutrition was taken and which, like nature at the onset of winter, are exhausted relics. On one hand they invoke the "lonely country boy....with a sink full of dirty dishes" from "Where are you Tonight,"12 and gesture once again towards the domestically imprisoned woman in other Junkies songs like "Horse in the Country"13 and "Brand New World." ${ }^{14}$ Here though, the dishes and the glass also become the anathemata of a domestic ritual of renewal as he "lifts his glass" from their table/altar. The moisture which leaves the ring on the table contrasts nicely with the wedding ring left on the sill to keep it dry and resonates with the mysterium coniunctionus, or alchemical wedding of opposites. The sip of the drink from his chalice, which he shares with his wife, becomes the conclusive sacramental gesture of the ritual a few stanzas on.

Another noteworthy meme of this song is silence. The narration is entirely exterior to its pair of protagonists. It's not a stream-of-consciousness approach like "Horse in the Country" or the ones to which I think it bears its strongest kinship, "Winter Song” and “Cold Tea Blues.”" The protagonists do not speak to each other; they are, for the most part, feeling their way through their estrangement, communicating through touch - "he sees the light from the window caress her / like he knows he should," "he puts the ring on her finger / she brushes back his hair.” But this silence does more than emphasize the alienation that has settled in between the couple. The subdued tone of the song's first pair of stanzas suddenly gives way to its bridge, with Margo Timmins' voice rising in volume and intensity to deliver its summons to relive past experiences wherein her narratee is alone with one startlingly violent image- “you knew they would cut right through you / and once inside you were afraid they'd find nothing to hold onto.” This evisceration imagery points beyond its purely metaphorical sense of personal insecurity to the aforementioned ritual dismemberment of the ancient mythic ethos of the sacred marriage, frequently enacted as a sacrifice. Of course, it also suggests the emptying out of the ego which is necessary to forge intimacy with another. This sacrifice of the ego, in turn, foregrounds the unmistakable Eucharistic references implicit in the husband's glass/chalice and the empty dishes. Its symbolic constellation originates in the same sacrificial rite towards which the Easter drama always gestures: to the consumed paschal lamb and the divinely sanctioned cannibalism of the Eucharist itself - to "the taste that he left on her tongue.” And finally, the bridge reaffirms the spiritual theme undergirding the entire poem; it asks of both protagonists, "do you remember when you prayed [my emphasis] to never see the day / when someone would make you feel this way." An exhortation to remember, the lyrics suggest fear of intimacy, fear of the ego-death by which intimacy becomes even possible, lies behind "the fear that they feel" and may be the key to their estrangement.

But the tongue is also a reflexive metaphor of the enunciation of all these themes in language, or in this case, in what Aristotle referred to as melos, of poetry set to music. It's the image that, by symbolizing the direct contact of the senses with the world, consolidates all the domestic desiderata grounding this song in day-to-day experience, keeps it from being overwhelmed by its mythic allusions, and preserves its gentle humanity.

\footnotetext{
12 The Caution Horses. New York: RCA (1990), track 8.

13 Black Eyed Man, track 4.

14 At the End of Paths Taken. Toronto: Latent (2007), track 1.

${ }^{15}$ Pale Sun, track 9.
} 


\section{Conclusion: Rythms of Life, Death and Love}

Like so many of Timmins' mythopoetically charged lyrics, “Ring on the Sill” subsumes an uncanny richness of layered mythological, archetypal and religious references behind its moment of quotidian family life or concrete natural images borne of the seasonal cycle, and carries an immense freight of emotion without sentimentality. In "Ring," as in "First Recollection” and "Winter Song," among many, the waxing and waning of exquisite emotions like love and darker reaches of the soul like despair become, in their syncretism with the rhythms of the seasons, natural phenomena themselves. Timmins' seasons are arcs of the spirit as well as the natural world. They are indistinguishable in their organic being from the cold of winter, the meltwater of spring, the warmth of summer or the disengagement of autumn.

\section{References}

Hopkins, G. M. (1985). That nature is a heraclitean fire and of the comfort of the resurrection. Poems and prose. New York: Penguin Classics.

Mills, J. L. (1996). Equine Gothic. The Southern Literary Journal, 29(1), 2-17

Pound, E. (1957). Ballad of the goodly fere. Selected poems. New York: New Directions.

Cross, F. L., \& Livingstone, E. A. (1997). (Eds.) The Oxford Dictionary of the Christian Church (3rd ed.). Oxford: Oxford University Press. 